$\mathrm{O}$ gólnopolska konferencja naukowa $^{1}$ pod tym tytułem zorganizowana przez Katedrę Informacji Naukowej i Bibliologii Uniwersytetu Kazimierza Wielkiego w Bydgoszczy odbyła się w dniach 8-9 października w Zespole Pałacowo-Parkowym w Ostromecku. Tegoroczne spotkanie było poświęcone nowym obliczom przestrzeni informacyjnej $\mathrm{w}$ dobie Web 2.0. Celem konferencji było podjęcie dyskusji nad zmianami w przestrzeni informacyjnej pod wpływem nowych technologii, szczególnie w dobie sieci 2.0 i usług interaktywnych, rolą mediów w Internecie drugiej generacji, procesami tworzenia, wyszukiwania i udostępniania zasobów multimedialnych, jak i rolą bibliotek, muzeów i archiwów w tych procesach. Ważnymi tematami dyskusji były również nowe kanały komunikacji naukowej i ich wykorzystanie przez twórców i użytkowników informacji oraz rola i promocja usług biblioteczno-informacyjnych w przestrzeni Internetu drugiej generacji.

${ }^{1}$ Informacje i aktualności na jej temat znajdują się na stronie internetowej wydarzenia: Ogólnopolska konferencja naukowa. Nowe oblicza przestrzeni informacyjnej $w$ dobie WEB 2.0 [online] [dostęp: 30 czerwca 2015]. Dostępny w World Wide Web: http://www.konferencja.kinib.ukw. edu.pl/.

\section{Nowe oblicza przestrzeni informacyjnej w dobie Web 2.0}

DOI: http://dx.doi.org/10.12775/TSB.2015.010

Uczestnicy konferencji mieli okazję wysłuchać 22 referatów, które były przedstawione w czterech sesjach. Obrady były poprzedzone powitaniem zebranych gości przez dr hab. Annę Koziczak, dziekana Wydziału Administracji i Nauk Społecznych Uniwersytetu Kazimierza Wielkiego [dalej: UKW], ks. dr. hab. Zdzisława Kropidłowskiego, kierownika Katedry Informacji Naukowej i Bibliologii UKW i sekretarza konferencji dr Katarzynę Domańską (UKW). Konferencję uświetnili swoją obecnością dyrektorzy bibliotek regionu: dr Krzysztof Nierzwicki, dyrektor Biblioteki Uniwersyteckiej w Toruniu [dalej: BU UMK], Bożena Bednarek-Michalska, z-ca dyrektora BU UMK, Ewa Pronobis-Sosnowska, dyrektor Pedagogicznej Biblioteki Wojewódzkiej w Bydgoszczy, Ewa Stelmachowska, dyrektor i Danuta Kaczmarek, z-ca dyrektora Wojewódzkiej i Miejskiej Biblioteki Publicznej w Bydgoszczy oraz Lidia Derfert-Wolf przedstawiciel Biblioteki Głównej Uniwersytetu Technologiczno-Przyrodniczego w Bydgoszczy. 
W czasie konferencji referaty wygłosili zarówno przedstawiciele środowisk akademickich kształcących w zakresie bibliotekoznawstwa i informatologii, jak i pracownicy bibliotek naukowych.

Referatem inaugurującym pierwszą sesję pt. „Informatologia i informacja a przestrzeń Internetu” był „iSchools nieunikniony etap ewolucji czy koncepcja kształcenia z zakresu informatologii?”. Wygłosiła go dr hab. Małgorzata Fedorowicz-Kruszewska (Uniwersytet Mikołaja Kopernika w Toruniu, dalej: UMK). Omówiła koncepcje iSchools szkół wyższych, których celem jest rozwój nauki o informacji (i-Field), promowanie interdyscyplinarnego podejścia do zarządzania informacją oraz koncentracja na informacji jako przedmiocie badań i edukacji. Bardzo interesujące było przedstawianie najnowszych zmian w zakresie edukacji pracowników informacji naukowej i bibliotekoznawstwa, zmian nazw kierunku i ich tendencji rozwoju w Polsce. Drugi referat: „Prywatność internetowa - zagrożenia i ochrona" zaprezentował dr Piotr Siuda (UKW), który przedstawił sprawy związane z naruszeniami prywatności internetowej użytkowników sieci. Celem jego wystąpienia była próba teoretycznego uporządkowania kwestii wspomnianych naruszeń. Autor, interpretując różne doniesienia akademickie, dokonał konceptualizacji prywatności internetowej, wskazał podstawowe typy jej naruszeń oraz sposoby przeciwdziałania im. Kolejny referat: „Baza wiedzy DBpedia - semantyczne oblicze Wikipedii" został przedstawiony przez dr Iwonę Filipowicz (UKW). Autorka omówiła nowe oblicze Wikipedii - nieustannie rozwijającą się bazę wiedzy DBpedię w kontekście stosowanych technologii oraz narzędzi semantycznych. Kolejny referat: „Cyberprzemoc - nowy rodzaj patologii społecznej związany z wykorzystaniem technologii informacyjno-komunikacyjnych" wygłosiła dr Magdalena Cyrklaff z Wyższej Szkoły Bankowej w Toruniu. Autorka opisała jeden z nowych rodzajów patologii komunikowania występujących w Internecie: cyberprzemoc. Dokonała ustaleń definicyjnych i opisała przyczyny pojawiania się e-przemocy, a także omówiła jej atrybuty oraz rodzaje.

Drugiej sesji: „Nowe technologie w przestrzeni informacyjnej" przewodniczyła dr hab. Jolanta Dzieniakowska (Uniwersytet Jana Kochanowskiego w Kielcach, dalej: UJK), a otworzyła ją referatem „Ukryty Internet - nowe podejście" dr Natalia Pamuła-Cieślak (UMK). Wystąpienie było próbą nowego spojrzenia na zjawisko sieci głębokiej przez pryzmat zmieniających się technologii i skutków, jakie mają one dla udostępniania i wyszukiwania informacji. Referentka dokonała analizy rynku wyszukiwawczego w Internecie poprzez prześledzenie tren- 
dów rozwojowych zarówno najpopularniejszych, jak i wyspecjalizowanych interfejsów wyszukiwawczych. Opisała je w kontekście zachowań informacyjnych użytkowników sieci WWW. Następny referat: „Crowdfunding alternatywne źródło finansowania w dobie Web 2.0" przedstawiła dr Małgorzata Kowalska (UMK). Omówiła istotę crowdfundingu, wskazała istniejące modele finansowania społecznościowego i rodzaje inicjowanych projektów. Szczególną uwagę skupiła na przedstawieniu wybranych polskich przykładów platform crowdfundingowych i dokonała oceny efektywności prowadzonych inicjatyw, zwłaszcza tych realizowanych przez instytucje GLAM (ang. galleries, libraries, archives, museums). W kolejnym wystąpieniu tej sesji dr K. Domańska (UKW) przybliżyła problematykę serwisów edukacyjnych w przestrzeni Web 2.0. Autorka dokonała analizy zawartości serwisów edukacyjnych przeznaczonych przede wszystkim dla uczniów i nauczycieli. Podzieliła je na kilka grup: oficjalne strony urzędów i instytucji (szczebla ogólnopolskiego i regionalnego) zajmujących się oświatą, specjalistyczne serwisy prowadzone przez wspomniane urzędy i instytucje, polskojęzyczne strony oświatowych programów unijnych, witryny edukacyjne prowadzone przez wydawnictwa, serwisy organizacji pozarządowych działających w sferze edukacji oraz strony tworzone przez przedsiębiorstwa i osoby prywatne. Tematyka wpływu technologii informacyjno-komunikacyjnych (ICT) na zmiany w bibliotekach akademickich została poruszona przez mgr Edytę Kołodziejczyk (Biblioteka Politechniki Łódzkiej). Autorka omówiła transformacje, jakie zachodzą w technologii, badaniach naukowych, uczeniu się i nauczaniu, które wyznaczyły bibliotekom nowy kierunek. Technologia informacyjno-komunikacyjna (ICT) znalazła zastosowanie w każdej strefie działalności bibliotecznej i objęła swoim zasięgiem m.in. kwestie zarządzania, organizację przestrzeni, sposób świadczenia usług, system komunikacji z użytkownikiem. Na zakończenie tej sesji mgr Marcin Karwowski (UMK) w wystąpieniu: „Analiza biblioblogów jako kanałów komunikacji naukowej" dokonał analizy ilościowej i jakościowej zawartości wybranych blogów naukowych i popularnonaukowych z zakresu bibliologii i informatologii. Sprawdził, jaki wpływ mają edukacja i miejsce pracy autora na tematykę publikowanych postów oraz ich częstotliwość. Wyniki analizy przedstawił $\mathrm{w}$ formie: zestawień ilościowych i treściowych publikowanych informacji, sylwetek blogerów, rankingu najaktywniejszych blogerów oraz katalogu blogów z podziałem tematycznym.

Trzecia sesja: „Biblioteki w przestrzeni informacyjnej sieci WWW", pro- 
wadzona była przez dr. hab. Zdzisława Gębołysia, prof. UKW. Otwierało ją wystąpienie dr hab. J. Dzieniakowskiej (UJK) pt. „Biblioteki szkolne w cyberprzestrzeni? Uwagi o promocji książnic szkół podstawowych". Referat był próbą oceny, w jakim stopniu i z jakim skutkiem biblioteki szkół podstawowych wykorzystują nowe technologie w swych działaniach promocyjnych. Stosowanie nowych mediów zwiększa szanse na wzrost zainteresowania biblioteką, a także na nawiązanie kontaktu z dziećmi i młodzieżą, również w sferze relacji bezpośrednich. Dr Stanisław Skórka, dyrektor Biblioteki Głównej Uniwersytetu Pedagogicznego w Krakowie, zaprezentował wystąpienie pt. „Katalogi bibliotek w smartfonach. Analiza użyteczności i architektury informacji". Przedstawił w nim wyniki badań pilotażowych wybranych elektronicznych katalogów bibliotek w wersji na smartfony. Analizie porównawczej poddał architekturę informacji i użyteczność aplikacji. Następny prelegent, dr Paweł Marzec (UKW) przybliżył problematykę zatytułowaną „Dostępność serwisów internetowych różnych typów bibliotek na urządzeniach mobilnych", która bardzo dobrze korelowała z poprzednim wystąpieniem. Omówił badania dotyczące dostępności serwisów internetowych różnych typów bibliotek na urządzeniach mobilnych. Przedstawił wyniki analizy ilościowej oraz jakościowej serwisów lub aplikacji mobilnych wybranych typów bibliotek w Polsce. Celem jego badań była próba określenia stopnia realizacji usług bibliotecznych w zakresie Internetu mobilnego. Dr Monika Olczak-Kardas (UJK) na wybranych przykładach zaprezentowała referat pt. „Strony internetowe bibliotek pedagogicznych - narzędziem promocji i komunikacji z użytkownikiem". Autorka dokonała analizy stron internetowych wybranych bibliotek pedagogicznych. Określiła, w jakim stopniu i do jakich celów biblioteki wykorzystują nowe technologie. Problematykę obecności druków włocławskich 1850-1918 w bibliotekach cyfrowych omówiła dr Bernardeta Iwańska-Cieślik (UKW). Dokonała analizy zawartości bibliotek cyfrowych pod kątem występowania druków włocławskich. Prezentacją zamykającą tę sesję i pierwszy dzień obrad był referat „Klasyfikacje w dobie Internetu” dr Jolanty Hys z Biblioteki Narodowej w Warszawie. Autorka omówiła uniwersalne klasyfikacje biblioteczne (Uniwersalna Klasyfikacja Dziesiętna; Klasyfikacja Dziesiętna Deweya; Klasyfikacja Biblioteki Kongresu) oraz klasyfikacje dziedzinowe (Mathematics Subject Classification; National Library of Medicine Classification; ACM Computing Classification System; Iconclass; Klasyfikacja Dziedzinowa Książek w Bibliotece Uniwersytetu Papieskiego Jana Pawła II) w aspek- 
cie ich funkcjonowania w katalogach bibliotek w XXI w.

Drugi dzień konferencji i ostatnią sesję „Zasoby informacyjne w przestrzeni Internetu" prowadziła i moderowała dr hab. M. Fedorowicz-Kruszewska (UMK). Pierwszy wygłoszony w niej referat, autorstwa dr Elżbiety Pokorzyńskiej (UKW), dotyczył baz opraw zabytkowych. Zostały tu przybliżone i porównane wybrane bazy opraw, przedstawiono refleksję nad wybranymi elementami opracowania, ich wartością i celowością. Standaryzacja elementów opisu, możliwości wyszukiwawcze, możliwość dodawania obiektów oraz poprawiania opisów, szerokie upowszechnienie w Internecie to argumenty, które skłaniają do tworzenia tego rodzaju kolekcji cyfrowych. „Obecność elementów Web 2.0 w serwisach branży wydawniczo-księgarskiej" omówiła dr Wanda A. Ciszewska (UMK). Autorka podjęła próbę oceny funkcjonalności branżowych serwisów wydawniczo-księgarskich jako źródła informacji, a zarazem profesjonalnego wsparcia w działalności zawodowej. Dr Kazimierz Adamczyk (UKW) zaprezentował referat: „Przestrzeń informacji cyfrowej w Bibliotece Uniwersytetu Kazimierza Wielkiego w Bydgoszczy", który przygotował wraz z innymi pracownikami biblioteki, mgr Małgorzatą Zmitrowicz i mgr. Maciejem Weryho. Zaprezentował najważniejsze obszary działalności Biblioteki
UKW w przestrzeni obiegu informacji cyfrowej, dystrybuowanej online. Są wśród nich zarówno klasyczne, tradycyjne funkcje biblioteki, realizowane obecnie w wersji elektronicznej, jak katalog biblioteczny czy bibliografia publikacji pracowników uniwersytetu, ale także inicjatywy powstałe już w dobie cyfrowej, z pełnym wykorzystaniem jej specyfiki, jak biblioteka cyfrowa, repozytorium, blog czy Archiwum Historii Mówionej. Kolejne wystąpienie poświęcone było systemom CMS i ich relacji z Web 2.0. Referat zaprezentowany został przez mgr. Mariusza Jarockiego (UMK), który omówił trzy najpopularniejsze systemy zarządzania treścią (CMS): WordPress, Joomla! i Drupal. Autor zwróci szczególną uwagę na możliwości ich współpracy z serwisami społecznościowym, blogami, podcastami i serwisami wiki, a także na występujące w nich mechanizmy nadawania tagów. Kolejny referat: „Górska przestrzeń informacyjna Internetu" wygłosiła dr Beata Przewoźnik (Uniwersytet Śląski w Katowicach). Dokonała w nim analizy i oceny zjawiska górskiej informacji internetowej w dobie Web 2.0. Podstawą analizy zjawiska informacji górskiej w Internecie były głównie obecne w elektronicznej formie wybrane czasopisma górskie dostępne online oraz strony bibliotek przechowujących zbiory o tematyce górskiej. Przedstawiła także fora dyskusyjne jako formę komunikacji 
i wymiany informacji pasjonatów turystyki i sportów górskich. Dr Dariusz Spychała (UKW) przybliżył problematykę antyku w Internecie. Omówił przede wszystkim kolekcje cyfrowe zawierające treści antyczne. Ostatnim referatem, zamykającym konferencję, było wystąpienie ks. dr. hab. Z. Kropidłowskiego (UKW). Autor przedstawił w nim projekt pt. „Republika Listów” (ang. Early Modern Letters Online EMLO), który jest realizowany przez środowisko Bodleian Digital Library Systems and Services przy współpracy Wydziału Humanistycznego Uniwersytetu Oksfordzkiego i dzięki finanso- waniu Fundacji Andrew W. Mellona. Projekt ten stawia sobie za cel opublikowanie $\mathrm{w}$ przestrzeni Web 2.0 wszystkich zachowanych listów $\mathrm{z}$ lat 1550-1750. Podsumowania konferencji dokonały dr hab. E. Głowacka i dr hab. M. Fedorowicz-Kruszewska (UMK). Wygłoszone referaty ukażą się w planowanej monografii pokonferencyjnej.

\section{Katarzyna Domańska} Katedra Informacji Naukowej i Bibliologii Uniwersytetu Kazimierza Wielkiego w Bydgoszczy

\section{Biblioteka, książka, informacja i Internet 2014}

DOI: http://dx.doi.org/10.12775/TSB.2015.011

Celem konferencji było dokonanie przeglądu stanu badań naukowych oraz rozwiązań praktycznych w kilku obszarach tematycznych. Dotyczyły

nr 51. Z dwóch pozostałych przygotowano monografie: Biblioteka, książka, informacja, Internet 2010, pod red. Z. Osińskiego, Lublin 2010 oraz Biblioteka, książka, informacja, Internet 2012, pod red. Z. Osińskiego i R. Malesy, Lublin 2013. były się w latach 2008, 2010, 2012. Materiały z pierwszej konferencji ukazały się w czasopiśmie „Folia Bibliologica” 2009, 